\title{
Implications of local soil knowledge for integrated soil management in Latin America
}

\author{
E. Barrios ${ }^{\mathrm{a}, *}$, M.T. Trejo

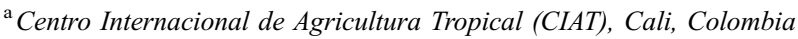 \\ ${ }^{\mathrm{b}}$ Centro Internacional de Agricultura Tropical (CIAT), Tegucigalpa, Honduras
}

\begin{abstract}
The increasing attention paid to local soil knowledge in recent years is the result of a greater recognition that the knowledge of people who have been interacting with their soils for long time can offer many insights about the sustainable management of tropical soils. This paper describes two approaches in the process of eliciting local information. Case studies show that there is a consistent rational basis to the use of local indicators of soil quality and their relation to improved soil management. The participatory process used is shown to have considerable potential in facilitating farmer consensus about which soil-related constraints should be tackled first. Consensus building is presented as an important step prior to collective action by farming communities in integrated soil management at the landscape scale. Taking advantage of the complementary nature of local and scientific knowledge is highlighted as an overall strategy for sustainable soil management.
\end{abstract}

(C) 2002 Published by Elsevier Science B.V.

Keywords: Collective action; Colombia; Honduras; Landscape; Natural resource management; Participatory methodologies; Venezuela

\section{Introduction}

Local knowledge related to agriculture can be defined as indigenous skills, knowledge and technology accumulated by local people derived from their direct interaction with the environment (Altieri, 1990). It is the result of an intuitive integration of local agroecosystem responses to climate and land-use change through time (Barrios et al., 1994).

* Corresponding author.

E-mail addresses: e.barrios@cgiar.org (E. Barrios), ciat-honduras@cgiar.org (M.T. Trejo). 
Transfer of information from generation to generation undergoes successive refinement leading to a system of understanding of natural resources and relevant ecological processes (Pawluk et al., 1992). Winklerprins (1999) has provided a recent review of the scope and nature of the existing literature about local soil knowledge and the emerging science of ethnopedology.

There is increasing consensus about the need for enhanced understanding of local knowledge in planning and implementing development activities (CIRAN, 1993). The slow rate of assimilation of new technology and new cropping systems has been often attributed to local inertia rather than the failures to take into account the local experience and needs (Warren, 1991). According to Walker et al. (1995), increased application of indigenous knowledge to rural research and development can be attributed to the need to improve the target of research to address client needs and thus increase adoption of technological recommendations derived from research. Besides, ethical considerations related to participation and empowerment of local communities have gained considerable importance (Chambers, 1983).

The complementary role that indigenous knowledge plays to scientific knowledge in agriculture has been increasingly acknowledged (Sandor and Furbee, 1996). Experimental research is an important way to improve the information upon which farmers make decisions. It is questionable, however, if relying on experimental scientific methodology alone is the most efficient way to fill gaps in current understanding about the sustainable management of agroecosystems. There has been limited success of imported concepts and scientific interpretation of tropical soils in bringing desired changes in tropical agriculture. This has led an increasing recognition that the knowledge of people who have been interacting with their soils for long time can offer many insights about managing tropical soils in a sustainable way (Hecht, 1990).

Nevertheless, although benefits of local knowledge include high local relevance and potential sensitivity to complex environmental interactions, without scientific input local definitions can sometimes be inaccurate and unable to cope with environmental change. It is thus argued that a joint local/scientific approach, capitalizing on complementarities and synergies, would permit overcoming the limitations of site specificity and empirical nature and allow knowledge extrapolation through space and time as suggested by Cook et al. (1998).

The science of ethnopedology encompasses many aspects, including indigenous perceptions and explanations of soil properties and soil processes, soil classifications, soil management, and knowledge of soil-plant interrelationships (Talawar, 1996). This paper examines three case studies on local soil knowledge and management and the implications of these results on future research on integrated soil management in Latin America. Results from case studies to elicit local information using key informants are reported for small farmers from Orinoco floodplains in Venezuela and from the Cabuyal River watershed in Cauca, Colombia. A participatory approach was used with farmers from the Tascalapa River watershed in Yoro/Sulaco, Honduras, in order to identify and classify local indicators of soil quality related to permanent and modifiable soil properties. Finally, the potential of the latter approach as a mechanism to facilitate collective action leading to integrated soil management is discussed. 


\section{Case studies}

\subsection{Orinoco floodplain farmers from Venezuela}

The local knowledge about soils and their management by Orinoco floodplain farmers was studied by Barrios et al. (1994). A case study approach with key informants was used to highlight practices that lead floodplain farmers to high yields and economic success while improving or maintaining soil fertility (Anderson and Ingram, 1989; Brown et al., 1994). In this highly unpredictable environment, the basic assumption is that farmer's indigenous knowledge is the result of an intuitive integration of their perception of changes in the agroecosystem as a result of climatic changes, the major driving force for decision making. The systematic assessment of local knowledge about soils and their management focused on criteria used for selection of new agricultural sites in this typically slash and burn agriculture, for soil classification and soil texture "management" and for managing inherent soil variability.

In the Orinoco floodplains, when farmers are looking for new cropping land they make a first selection based on the type of vegetation growing on the soil. Therefore, traditional farmers use associations of native plants as indicators of soil quality. In order of importance, trees such as 'caujaro' (Cordia sp.), 'taparo' (Crescentia sp.) and 'yagrumo' (Cecropia sp.) and herbaceous species like 'gamelote' (Paspalum fasciculatum), 'paja de agua' (Paspalum repens), 'tarraya' (Glinus sp.) and 'borrajón' (Heliotropium indicum) were used as indicators of "good soils" (Table 1). Conversely, they also use native plants as indicators of where not to establish a cropping field. For instance, trees such as 'melero' (Combretum frangulaefolium) and 'toco' (Crataeva gynandra) as well as herbaceous species like 'yerbabuena' (Phyla betulaefolia) and the grasses 'pata colorada' and 'bochocha' were plants indicating

Table 1

Most important plant species used as local indicators of soil quality by Orinoco floodplain farmers (modified from Barrios et al., 1994)

\begin{tabular}{|c|c|c|c|c|}
\hline Common name & Scientific name & Botanical family & Plant type $^{\mathrm{a}}$ & Soil type \\
\hline Gamelote & Paspalum fasciculatum & Gramineae & $\mathrm{H}$ & Fertile \\
\hline Paja de agua & Paspalum repens & Gramineae & $\mathrm{H}$ & \\
\hline Tarraya & Glinus sp. & Aizoae & $\mathrm{H}$ & \\
\hline Borrajón & Heliotropium sp. & Boraginaceae & $\mathrm{H}$ & \\
\hline Caujaro & Cordia sp. & Boraginaceae & $\mathrm{T}$ & \\
\hline Pira & Amaranthus dubius & Amaranthaceae & $\mathrm{H}$ & \\
\hline Taparo & Crecentia cujete & Bignoniaceae & $\mathrm{T}$ & \\
\hline Yagrumo & Cecropia sp. & Moraceae & $\mathrm{T}$ & \\
\hline Artemisa & Ambrosia cumanensis & Asteraceae & $\mathrm{H}$ & \\
\hline Granadilla & Polycarpea sp. & Caryophylaceae & $\mathrm{H}$ & \\
\hline Melero & Combretum frangulaefolium & Combretaceae & $\mathrm{T}$ & Poor \\
\hline Toco & Crataeva gynandra & Capparidaceae & $\mathrm{T}$ & \\
\hline Yerbabuena & Phyla betulaefolia & Verbenaceae & $\mathrm{H}$ & \\
\hline Pata colorada & s.n.n.i. ${ }^{b}$ & Gramineae & $\mathrm{H}$ & \\
\hline Bochocha & s.n.n.i. ${ }^{b}$ & Gramineae & $\mathrm{H}$ & \\
\hline
\end{tabular}

${ }^{\text {a }}$ Plant type: $\mathrm{H}=$ herbaceous, $\mathrm{T}=$ tree.

${ }^{\mathrm{b}}$ s.n.n.i. = scientific name not identified. 
"bad soils". It is not surprising that farmers use vegetation in their first evaluation of potential cropping sites since these integrate complex and often diffuse soil attributes.

Once the agricultural plot has been selected, a more detailed examination of the soil allows farmers to plan crop and soil management activities. While darker colored soils are generally recognized as better soils, local farmers identified soil texture as the most important measure on which to select crop and soil management practices. Farmers recognized the importance of fine texture sediment in floodplain soil fertility. Given the great uncertainty of sediment quality every year as influenced by flooding regimes, a traditional system to manage the quality of the incoming sediments was developed by floodplain farmers (Barrios et al., 1994). Vegetation barriers are allowed to grow or are planted by farmers around their agricultural plots in order to "filter" the coarse sediment and only allowing the finer sediment into the plots. Vegetation barriers are typically composed of trees like 'Jariso' (Ruprectia sp.), 'guayabo rebalsero' (Psidium ovatifolium) and grasses like 'gamelote' (P. fasciculatum) (Fig. 1).

Soil heterogeneity is very conspicuous because of the uneven distribution of sediment throughout the floodplain. The use of different crops in areas with different soil texture by traditional farmers shows an optimization of soil resource use. This could be seen as a traditional basis for modern site-specific management! Local wisdom indicates that while certain crops only grow well in specific soil textures, e.g. watermelon in sandy soil, beans in clay soil and cotton in mixed soil, other crops such as maize and cowpea are ubiquitous and are found in all soil textures (Barrios, 1997).

\subsection{Andean hillside farmers from Colombia}

Studies on local knowledge about soils and their management were conducted within the Cabuyal watershed, Cauca department, Colombia using case study approaches with

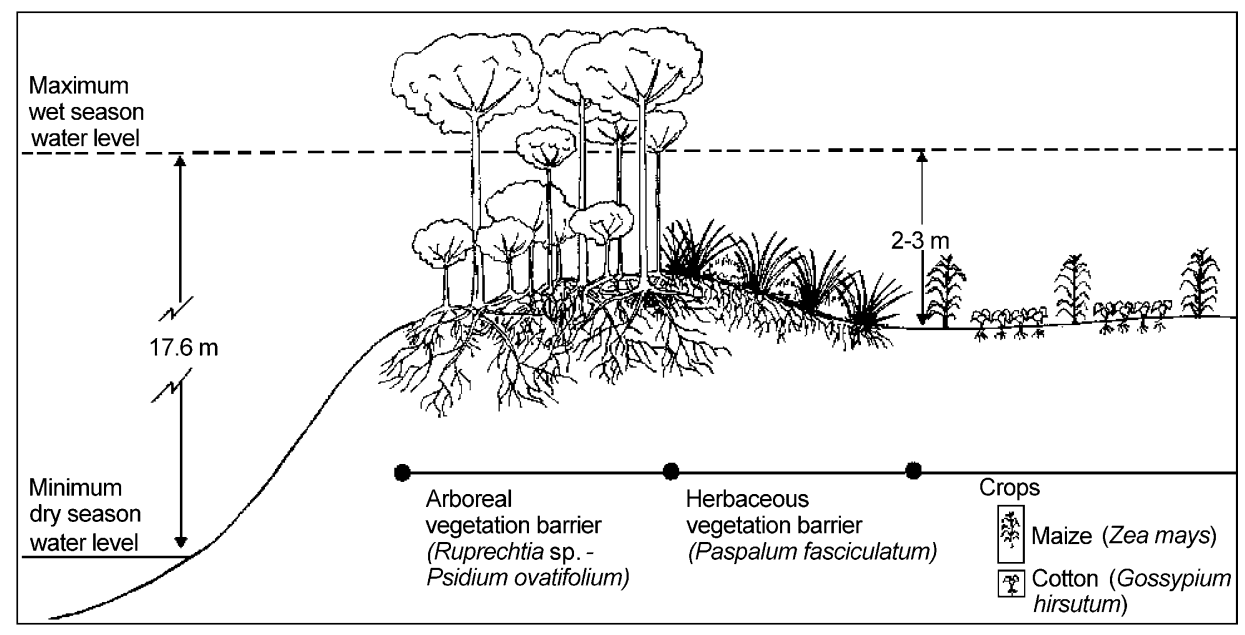

Fig. 1. Schematic diagram of vegetation barriers used by Orinoco floodplain farmers to manage the quality (particle size) of the incoming sediment into their agricultural plots (modified from Barrios et al., 1994). 
semi-structured questionnaires, participatory farm mappings of soil qualities and identification of local indicators used to discriminate among different soils (Trejo et al., 1999). Previous studies in the area by Centro Internacional de Agricultura Tropical (CIAT) during the last 15 years facilitated the identification of key informants from each village. Key informants were selected from eight villages in three altitudinal zones in the watershed (Salamanca, 2000). High elevation villages (1700-2200 m a.s.1.) included El Cidral, La Esperanza, La Primavera and El Rosario, middle elevation villages (1450-1700 m a.s.1.) included La Campiña and El Porvenir, and low elevation villages (1175-1450 m a.s.l.) included La Llanada and La Isla. In the predominantly young volcanic ash soils, Oxic Dystropepts in the USDA soil classification system, 100\% of farmers interviewed use soil color for classification and assessment of soil quality. Black-colored soils are considered good for cropping and yellow and red soils are considered marginal. Black soils are often found in soils under forest, fallow or pastures. Increasing use of tillage has lead to increased rates of soil loss and thus the usually darker topsoil has given way to the red subsoil where cultivation is now taking place in many agricultural plots.

Native plants constitute another means by which Andean hillside farmers classify the soils in their farms (Barrios and Escobar, 1998). In Table 2, we find native plants used as indicators of soil quality by farmers in the Cabuyal River watershed. Fertile soils are characterized by trees like 'nacedero' (Trichanthera gigantea) and 'guamo' (Inga sp.) and herbaceous plants like 'papunga' (Bidens pilosa) and 'mariposo' (Clibadium surinamensis) while plants predominating in poor soils invariably include 'helecho marranero' (Pteridium aquilinum) and 'paja garrapatera' (Andropogon bicornis). Farmers also identify ubiquitous species such as 'yaraguá' (Mellinis minutiflora) and 'caracola' (Koheleria lanata) which are then characterized by their vigor and leaf color. Darker green colored

Table 2

Most important plant species used as local indicators of soil quality by Cabuyal watershed hillside farmers, Colombia (modified from Barrios and Escobar, 1998)

\begin{tabular}{|c|c|c|c|c|}
\hline Common name & Scientific name & Botanical family & Plant type $^{\mathrm{a}}$ & Soil type \\
\hline Papunga & Bidens pilosa & Asteraceae & $\mathrm{H}$ & Fertile \\
\hline Mariposo & Clibadium surinamensis & Asteraceae & $\mathrm{H}$ & \\
\hline Margarita & Chaptalia nutans & Asteraceae & $\mathrm{H}$ & \\
\hline Mortiño & Clidemia hirta & Meliaceae & $\mathrm{H}$ & \\
\hline Altusara & Phytolacca americana & Phytolaccaceae & $\mathrm{H}$ & \\
\hline Siempre Viva & Commelina difusa & Commelinaceae & $\mathrm{H}$ & \\
\hline Hierba de chivo & Ageratum conyzoides & Asteraceae & $\mathrm{H}$ & \\
\hline Nacedero & Trichantera gigantea & Acanthaceae & $\mathrm{T}$ & \\
\hline Cachimbo & Erythrina sp. & Leguminosae & $\mathrm{T}$ & \\
\hline Guamo & Inga $\mathrm{sp}$. & Leguminosae & $\mathrm{T}$ & \\
\hline Helecho marranero & Pteridium aquilinum & Pteridiaceae & $\mathrm{H}$ & Poor \\
\hline Paja garrapatera & Andropogon bicornis & Poaceae & $\mathrm{H}$ & \\
\hline Paja blanca & Andropogon leuchostachys & Poaceae & $\mathrm{H}$ & \\
\hline Helechillo & Dichranopteris flexosa & Pteridaceae & $\mathrm{H}$ & \\
\hline Yaraguá & Mellinis minutiflora & Poaceae & $\mathrm{H}$ & Any soil \\
\hline Caracola & Koheleria lanata & Gesneriaceae & $\mathrm{H}$ & \\
\hline
\end{tabular}

\footnotetext{
a Plant type: $\mathrm{H}=$ herbaceous, $\mathrm{T}=$ tree.
} 
leaves are associated with more fertile soils while yellowish colors are indicative of poor soils.

Soils are also classified by their structure into "polvoso' or "powdery", that is, with no macroaggregates indicating degraded soils on one hand, and 'granoso' or "grain-like" which indicates some level of aggregation associated with better soils. This is an important characteristic used by farmers to assess soil recuperation after degraded soils have been left uncultivated to "rest" or fallow. In these hillside soils, topographic position also plays an important role in local soil classification. Hill tops or 'cimas' are identified as containing poorer soils, while the quality of hillsides or 'lomas' depends on how steep the slope is. The more fertile soils are concentrated in the flat areas or 'planadas', hollowed areas or 'huecadas' because of the accumulation of eroded soils lost from up the hill as well as riverine floodplains by deposition of nutrient-rich sediments (Cerón, 2000). Inherently infertile soils are named 'tierra brava' or "angry soils" which should be distinguished from "tierra cansada' or "tired soils" which are soils degraded by inappropriate management. Farmers consider that while the former are likely to respond to fertilizer applications (i.e. chicken manure) the latter invariably needs a period of fallow phase to recover lost attributes.

\subsection{Central American hillside farmers from Honduras}

A participatory approach was used in Honduras to identify and classify local indicators of soil quality and details can be found in Trejo et al. (1999). In short, six communities were selected from the Tascalapa watershed, namely Santa Cruz, Mina Honda (higher zone), San Antonio, Jalapa and Luquigue (middle zone) and Pueblito (lower zone) to identify and classify local indicators of soil quality at a landscape scale. Brainstorming sessions with farmer groups from the six communities, respectively, were followed by a prioritization phase where farmers from each community were split in smaller groups in order to rank local soil quality indicators identified according to their relative importance using paper cards. The final list of local indicators, in order of importance, was then integrated with their corresponding technical indicator in plenary sessions and organized into indicators of permanent (Table 3) and modifiable (Table 4) soil properties.

Although some local indicators can be rather general like fertility, slope, productivity and age under fallow, other local indicators are more specific. For instance, plant species growing in fallows, soil depth, color, water holding capacity and predominant soil particle sizes provide indicators that can be easily integrated with technical indicators of soil quality.

The classification of local indicators into permanent and modifiable factors provides a useful division that helps to focus on those where improved management could have the greatest impact. This strategy is particularly sound when there is considerable need to produce tangible results in a relatively short time in order to maintain farmer interest as well as to develop the credibility and trust needed for wider adoption of improved soil management practices.

Key permanent soil properties captured by local indicators that are commonly perceived as important by farming communities included slope, soil depth, soil color, soil texture and soil structure. The importance of slope in this hillside environment is 
Table 3

Integration of local and technical indicators of soil quality related to permanent soil properties in contrast sets identified and ranked according to their importance by Honduran hillside farmers from different villages (adapted from Turcios et al., 1998)

\begin{tabular}{|c|c|c|c|c|c|c|}
\hline \multirow[t]{2}{*}{ Ranking } & \multicolumn{6}{|l|}{ Knowledge integration } \\
\hline & Santa Cruz & Mina Honda & Jalapa & San Antonio & Luquigue & Pueblito \\
\hline 1 & $\begin{array}{l}\text { High water retention/ } \\
\text { low water retention } \\
\text { (texture/water holding } \\
\text { capacity) }\end{array}$ & $\begin{array}{l}\text { Spongy, "espolvoreado", } \\
\text { not sticky/“Arenisca", } \\
\text { hard, sticky (texture) }\end{array}$ & $\begin{array}{l}\text { Thick soil layer/thin } \\
\text { soil layer (soil depth) }\end{array}$ & $\begin{array}{l}\text { Deep or thick soil/ } \\
\text { thin soil (soil depth) }\end{array}$ & $\begin{array}{l}\text { Soil thickness of at least } \\
12 \mathrm{in} ., 2 \text { palms, half a } \\
\text { cutlass/thin soil less than } \\
4 \mathrm{in} \text { ( (soil depth) }\end{array}$ & $\begin{array}{l}\text { Flatlands/“"Tierras } \\
\text { quebradas" broken lands } \\
\text { (slope) }\end{array}$ \\
\hline 2 & $\begin{array}{l}\text { Thick top soil/thin top } \\
\text { soil (soil depth) }\end{array}$ & $\begin{array}{l}\text { Soil with a thick fertile layer/“frierra", } \\
\text { when fertile layer is very thin } \\
\text { or absent (soil depth) }\end{array}$ & $\begin{array}{l}\text { Soils with gentle } \\
\text { slopes, uniform/soils } \\
\text { with high slopes } \\
\text { (slope) }\end{array}$ & $\begin{array}{l}\text { Black color/light } \\
\text { color, yellowish, } \\
\text { reddish (color) }\end{array}$ & $\begin{array}{l}\text { Good holding of water, } \\
\text { soil that absorbs water/ } \\
\text { low water retention } \\
\text { (texture/water holding } \\
\text { capacity) }\end{array}$ & $\begin{array}{l}\text { Thick soil layer/thin soil } \\
\text { layer, "delgadita" } \\
\text { (soil depth) }\end{array}$ \\
\hline 3 & $\begin{array}{l}\text { Blackish/light colors } \\
\text { (color) }\end{array}$ & $\begin{array}{l}\text { "Tierra tendida", } \\
\text { "poca falda", little } \\
\text { slope/"Guindo", "abismo", } \\
\text { steep slopes (slope) }\end{array}$ & $\begin{array}{l}\text { Soil keeps water for } \\
\text { longer time/soil does } \\
\text { not keep water } \\
\text { (texture/water } \\
\text { holding capacity) }\end{array}$ & $\begin{array}{l}\text { Good plow } \\
\text { penetration/limited } \\
\text { plow penetration } \\
\text { (physical barriers) }\end{array}$ & $\begin{array}{l}\text { Easy to plow/difficult, } \\
\text { needs skill to plow } \\
\text { (physical barriers) }\end{array}$ & $\begin{array}{l}\text { "Harinita", flour-like, } \\
\text { "huestesita"/clay soil, } \\
\text { sandy soil (texture) }\end{array}$ \\
\hline 4 & $\begin{array}{l}\text { Flatter lands/“"Tierras } \\
\text { quebradas”, broken lands } \\
\text { (slope) }\end{array}$ & $\begin{array}{l}\text { Black color/“colorada", } \\
\text { reddish, "amarilla", } \\
\text { yellowish (color) }\end{array}$ & $\begin{array}{l}\text { Black/various soil } \\
\text { colors (color) }\end{array}$ & $\begin{array}{l}\text { Few stones/plenty of } \\
\text { large stones or } \\
\text { "lajas" (stoniness) }\end{array}$ & $\begin{array}{l}\text { Black color/yellow } \\
\text { color, "moreno", tan, } \\
\text { "colorada", reddish } \\
\text { (color) }\end{array}$ & $\begin{array}{l}\text { Black soils/reddish } \\
\text { soils, "medias } \\
\text { coloradas" (color) }\end{array}$ \\
\hline 5 & $\begin{array}{l}\text { Many stones/ } \\
\text { few stones (stoniness) }\end{array}$ & $\begin{array}{l}\text { "Suelos francos", loamy } \\
\text { soils/" barriales", clay, } \\
\text { mud, "arenoso", sandy } \\
\text { (texture) }\end{array}$ & $\begin{array}{l}\text { Fast water absorption/ } \\
\text { slow water absorption } \\
\text { (texture/infiltration) }\end{array}$ & $\begin{array}{l}\text { Little slope/steep } \\
\text { slope or "falda" } \\
\text { (slope) }\end{array}$ & $\begin{array}{l}\text { Loose rocks on topsoil, } \\
\text { not many stones/ } \\
\text { knowledge of rocks below } \\
\text { topsoil by inserting } \\
\text { machete (stoniness) }\end{array}$ & $\begin{array}{l}\text { Could have small } \\
\text { stones/have big stones } \\
\text { (stoniness) }\end{array}$ \\
\hline 6 & & $\begin{array}{l}\text { Small stones and few/ } \\
\text { many stones (stoniness) }\end{array}$ & $\begin{array}{l}\text { Loamy soils, little clay/ } \\
\text { "Brarrialosa" or muddy, } \\
\text { sandy } \\
\text { (texture/particle size) }\end{array}$ & $\begin{array}{l}\text { Loams "francos"/ } \\
\text { "Barrialosa", muddy, } \\
\text { much sand (texture) }\end{array}$ & $\begin{array}{l}\text { "Suelos francos", loamy } \\
\text { soils/“"areniscas", sandy } \\
\text { soils, "barrilosas" or clay } \\
\text { soils (texture) }\end{array}$ & $\begin{array}{l}\text { "No se ende", not a } \\
\text { cracking soil/“Se ende", } \\
\text { cracking soil } \\
\text { (clay type) }\end{array}$ \\
\hline 7 & & & $\begin{array}{l}\text { Easy tillage/difficult } \\
\text { tillage, "Tronconosa" } \\
\text { (physical barriers) }\end{array}$ & $\begin{array}{l}\text { "No se ende", non- } \\
\text { cracking soils/“Se ende", } \\
\text { cracking soils (clay type) }\end{array}$ & $\begin{array}{l}\text { "No se ende", non- } \\
\text { cracking soils/“Se ende", } \\
\text { cracking soils } \\
\text { (clay type) }\end{array}$ & \\
\hline 8 & & & $\begin{array}{l}\text { No stones present/ } \\
\text { "Balastrosa", stony, } \\
\text { gravely (stoniness) }\end{array}$ & & & \\
\hline
\end{tabular}


Table 4

Integration of local and technical indicators of soil quality related to modifiable soil properties in contrast sets identified and ranked according to their importance by Honduran hillside farmers from different villages (adapted from Turcios et al., 1998)

Ranking Knowledge integration

\begin{tabular}{llll}
\cline { 2 - 3 } Santa Cruz & Mina Honda & Jalapa \\
\hline 1 & $\begin{array}{l}\text { Fertile soil/non- } \\
\text { fertile soil } \\
\text { (fertility) }\end{array}$ & $\begin{array}{l}\text { "Revenideros", } \\
\text { washed land, } \\
\text { "tierra lavada"/ } \\
\text { "Tierra no lavada", } \\
\text { unwashed land } \\
\text { (erosion) }\end{array}$ & $\begin{array}{l}\text { "Opulento", no need } \\
\text { of chemical fertilizer/ } \\
\text { needs fertilization } \\
\text { (soil fertility) }\end{array}$ \\
& $\begin{array}{l}\text { Good yields given/ } \\
\text { bad yields given } \\
\text { Organic residue } \\
\text { incorporation of } \\
\text { organic residues } \\
\text { (soil organic } \\
\text { residues) }\end{array}$ & $\begin{array}{l}\text { Presence of } \\
\text { earthworms/lack of } \\
\text { earthworms } \\
\text { (biological activity) }\end{array}$ &
\end{tabular}

"Tierra blanda", "Buenos guamiles", Soil macroaggregates soft soil, "suelta", good fallows/ loose/"Tierra "Rastrojito", can be broken into pieces, "suelo suelto", San Antonio Luquigue Pueblito

"Opulento", Good plants, good crop,
high fertility/ low fertility lush and thick plants/

(soil fertility)

Bad plants, bad crops

(vegetation type/yield)

Soil is not poddled,

"no se aguachina"/ soil is poddled,

"se aguachina" (drainage)

"Verdolaga",

Soil incorporated/

amarrada", tied soil "bajillales",

loose soil/

(structure)

$$
\text { small fallows }
$$

macroaggregates

(Vegetation type)

cannot be broken,

"suelo amarrado",

tied soil (structure) "quilete",

"chichiguaste",

"chango",

"Pica pica",

"guama"/"tatascán",

"Pino" (indicator

plants)

High yields/low

yields (yields)

and malva/land with

washed soil (erosion)

"zacate" or native

pasture (indicator plants)

"Porosita", "despolvorienta", "Tierra se espolvorea", loose soil, "se desparrama", non-compacted/ soil is not compacted/ soil compacts as balls,

"No se desparrama",

compacted (structure)

"se amarra", it is tied

up (structure) 
Good weed growth/ "Terronosa", poor weed growth aggregated,

(type of vegetation) "suelta", loose/"Masiva", compacted (structure) No burning/burning Soil with a black (soil burning) litter or without

black layer
No burnings have occurred in the last 5 years/lands have been burned in the last

5 years (soil burning)

"Zaléa", "Chichiguaste"/ "Chichiguaste" does not grow, weeds do not develop, "zacate de (soil organic matter)

No burning/burning (soil burning)

\section{plants)}

Greater yields/lower yields, more work to produce (yield)

Soil does not flood, no "aguachina"//aguachina",

"sweaty" soil (drainage)

Nonwashed soils/washed soils (erosion)
Without "manto" or

incorporating

decomposing residues

with "manto"

(soil organic matter)

"Suelta", loose,

"suave", soft,

"terronosa", large

aggregates/"Tablones",

laminar structure

(structure)

No burning/burning

(soil burning)

"No se aguachina",

does not flood

"Se aguachina", gets muddy, water does not filter through (drainage)
New land use $<10$ years, from pasture to

cropland, land from ancestors was good/old

land, $>10$ years of use

(length of current land use)

No burning/burning

(soil burning)

No burning/burning (soil burning)

Does not occupy

fertilizer/needs

fertilizer (fertility)
"Manto", organic residues incorporated into the soil/

"Manto", not incorporated (soil organic matter)

Soil does not fill with water,

"No se empapa"/soil fills

with water, "Se empapa",

"pichera" (drainage)

Crops grow with little or no

fertilizer/only growth with

fertilizer (fertility)

Unwashed land/washed land

(erosion)

Ranking values are inversely related to degree of importance (i.e. $1=$ highest importance). 
obvious, as there is a maximum inclination under which agriculture can be practiced. Because of their topography, hillside soils are prone to erosive processes even under natural vegetation or appropriate management. These soils tend to be relatively shallow compared to valley soils and therefore local farmers identify a minimum soil depth required for crop root growth and development (i.e. 12 in., half a cutlass). Soil color provides a good measure of inherent soil fertility where black soils are seen as good soils and other red and yellowish colors as bad soils. Nevertheless, despite being classified as a permanent property, local farmers recognize that management practices involving crop residue additions could darken light-colored soils indicating improvement in their quality. Soil texture is considered important by local farmers because it affects soil water holding capacity as well as the resistance to tillage. Soil workability is also related to soil structure, as good soils are perceived as those that do not compact, and where soil aggregates can be broken by tillage.

Modifiable soil properties of importance were perceived as those related to the lack or presence of burning, the type of native vegetation and the soil biological activity indicated by the presence of soil organisms (i.e. earthworms). The earliest farmers have used fire as an agricultural management tool to recover nutrients held in the native vegetation biomass for the crops, to control pests and to dispose of perceived "excess" plant biomass in the fields (Sanchez, 1976). Despite the realization of the harm done by annual fires on the soil, the lack of farmer consensus that could lead to a concerted action appears to be an important limitation. The participatory methodologies presented here have the potential to facilitate consensus amongst the local farm community on high priority problems and opportunities. In this capacity, their linkage to concrete plans of action, as explained by Thomas et al. (in press), suggests this approach as a way to promote collective action at a landscape scale. A similar rationale has been successfully used in Africa to stimulate the participatory learning and action research process by Defoer and Budelman (2000).

It is important to note that the type of native vegetation present in a soil is a local indicator of soil quality (Table 5) that does not only cuts across the communities studied in Honduras but also across the other two case studies reported in this article. This observation suggests that there may be an underlying fundamental ecological principle

Table 5

Most important plant species used as local indicators of soil quality by Tascalapa watershed hillside farmers, Honduras (modified from Turcios et al., 1998)

\begin{tabular}{lllll}
\hline Common name & Scientific name & Botanical family & Plant type $^{\text {a }}$ & Soil type \\
\hline Chichiguaste & Eletheanthera ruderalis & Asteraceae & $\mathrm{H}$ & Fertile \\
Verdolaga & Portulaca oleraceae & Portulacaceae & $\mathrm{H}$ & \\
Malva & Anoda cristata & Malvaceae & $\mathrm{H}$ & \\
Zalea & Calea urticifolia & Asteraceae & $\mathrm{H}$ & \\
Guama & Inga sp. & Fabaceae & $\mathrm{T}$ & $\mathrm{H}$ \\
Quilete & Phytolaca icosandra & Phytolaccaceae & $\mathrm{H}$ & Poor \\
Pica pica & Mucuna pruriens & Fabaceae & $\mathrm{H}$ & \\
Zacate de gallina & Cynodon dactylon & Gramineae & $\mathrm{H}$ & \\
Tatascán & Perymenium nicaraguense & Asteraceae & $\mathrm{T}$ & \\
Pino & Pinus caribeae & Pinaceae & & \\
\hline
\end{tabular}

${ }^{\text {a }}$ Plant type: $\mathrm{H}=$ herbaceous, $\mathrm{T}=$ tree. 
behind farmer observations in the three locations. It is proposed here that one such ecological principle is that of natural succession as suggested by Paniagua et al. (1999). Natural and agricultural ecosystems respond similarly to degradation or regenerative processes through natural succession. The most adapted plants and organisms in the soil gradually replace less adapted ones as continued selective pressures are exerted (i.e. during regeneration of soil fertility or soil degradation). Native plants and "weeds", as biological indicators, have the potential to capture subtle changes in soil quality because of their integrative nature. They reflect simultaneous changes in physical, chemical and biological characteristics of the soil. There is considerable scope, therefore, to further explore the use of local knowledge about native plants as indicators of soil quality and as a tool for guiding soil management decisions.

\section{Implications for integrated soil management across the landscape}

Farmers are often more enthusiastic to empirical approaches (i.e. local knowledge, onfarm experiments) than prescriptive approaches (i.e. scientific knowledge, recipes for soil management) (Cook et al., 1998). Fig. 2 illustrates that while scientific information can be very precise its relevance can be relatively low. On the other hand, while local information can be relatively imprecise, yet, it can be very relevant. Although information should ideally be certain in both meaning and context, in reality this is not the case. Research efforts should further explore a suitable balance between precision and relevance as seen in the figure.

The methodological approach proposed by Trejo et al. (1999) goes beyond the identification and classification of local indicators of soil quality. It rests on the hypothesis that in order for sustainable management of the soil resource to take place, it has to be a result of improved capacities of the local communities to better understand agroecosystem

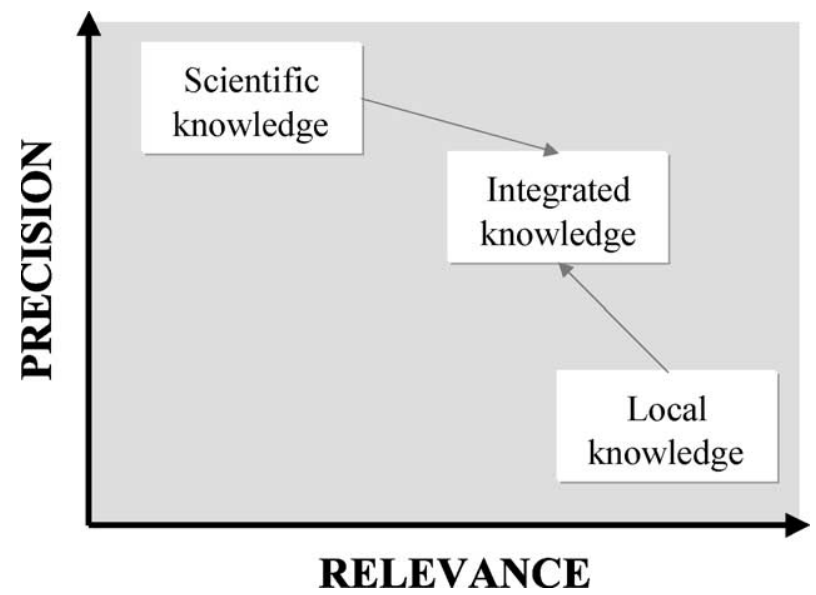

Fig. 2. Schematic representation of the comparison between scientific and local knowledge systems (modified from Cook et al., 1998). 

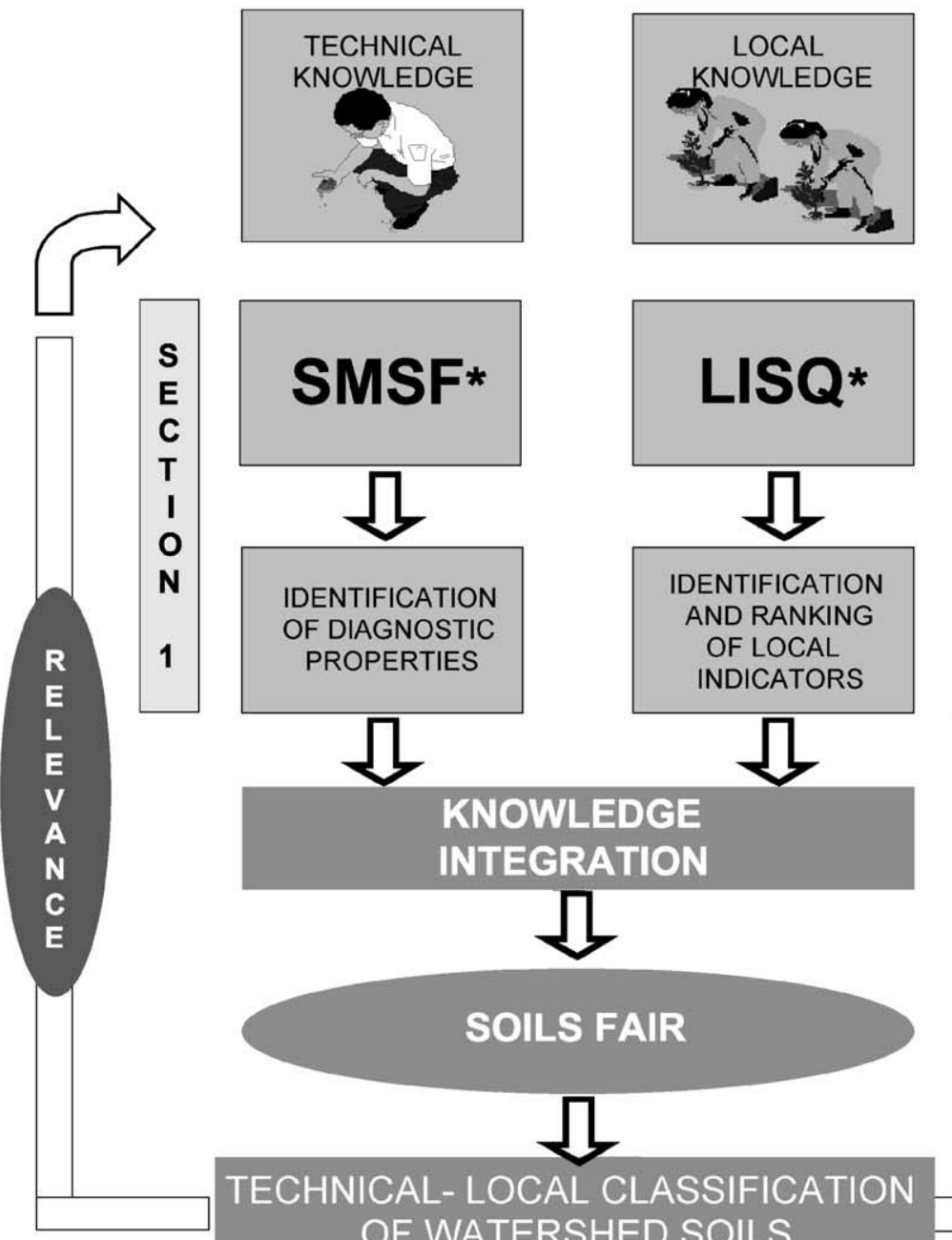

WLEDGE
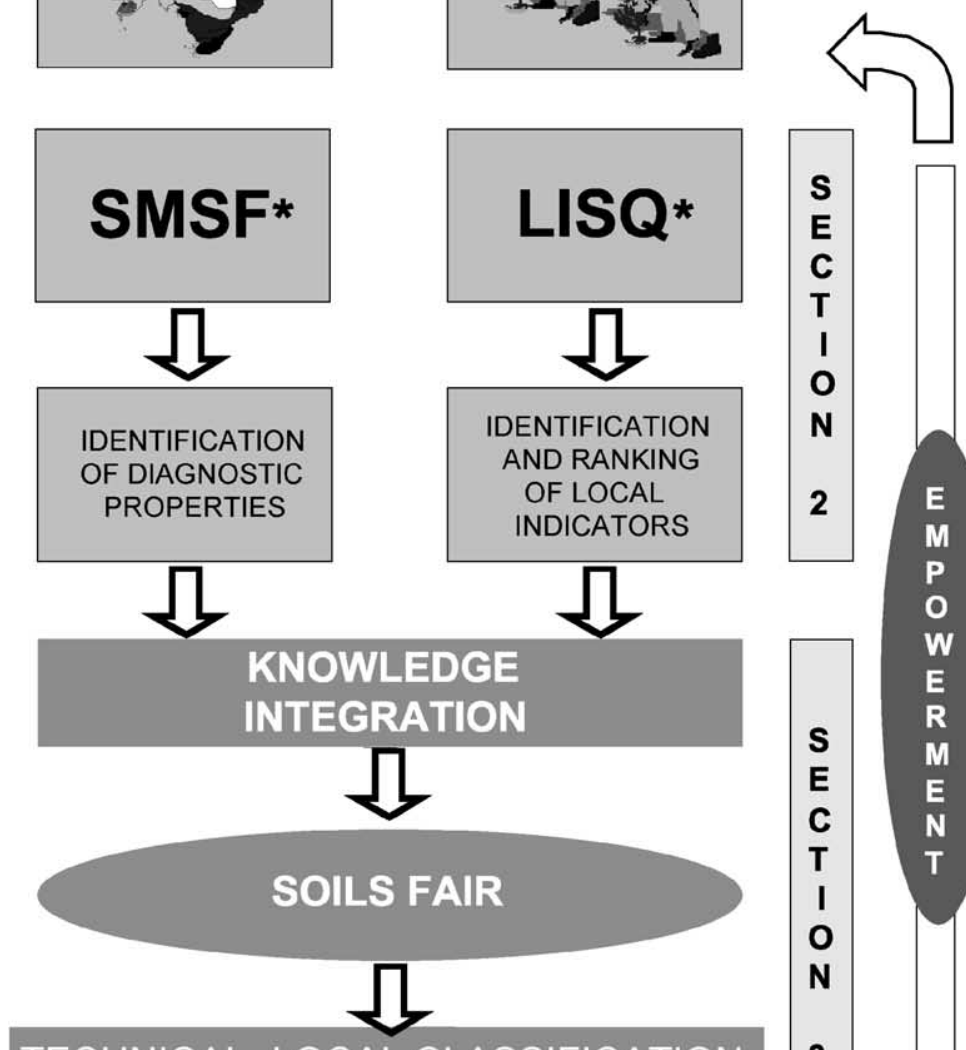

TECHNICAL- LOCAL CLASSIFICATION OF WATERSHED SOILS
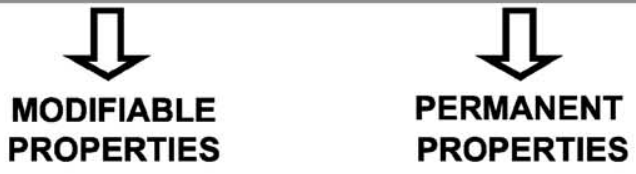

\section{${ }^{*}$ SMSF $=$ Simplified Model of Soil Formation \\ LISQ = Local Indicators of Soil Quality}

Fig. 3. Structure of the methodological guide for the participatory identification and classification of local indicators of soil quality (adapted from Trejo et al., 1999). 
functioning. Improved capacities by technical officers (extension agents, NGOs, researchers) to understand the importance of local knowledge is also part of the methodology. Therefore, after identifying if there is poor or a lack of adequate communication between the technical officers and the local farm community as a major constraint to capacity building, the methodology proposed deals with ways of jointly generating a common knowledge that is well understood by both interest groups. The structure of the guide in Fig. 3 shows the different sections of the methodological guide.

Section 1, which provides a general overview of soil formation factors and processes, based on Jenny's $(1941,1980)$ seminal work, is presented in order to bring the trainees (e.g. technical officers) to a common starting point. Section 2 deals with participatory techniques that help gather, organize and classify local indicators of soil quality through consensus building. Section 3 attempts to find correspondence between local indicators and technical indicators. This is carried out in a plenary session exercise of integration where the most important local indicators of soil quality are analyzed in the context of technical knowledge and are classified into indicators of permanent or modifiable soil properties. The idea is to provide a guideline to focus efforts on soil properties where management can have an impact. An important part of this section is the Soils Fair for farmers that is organized by the trainees. The Fair aims to help farmers develop skills to characterize relevant physical, chemical and biological properties of their soils through simple methods that can then be related to their local knowledge about soil management.

The result of this two-way exchange process has a positive impact on the technical knowledge by nurturing it with local perceptions and demands. The number of successful experiences in natural resource management in agroecosystems will likely increase because of the solid basis provided by local relevance. On the other hand, local knowledge will also be enriched because of greater possibilities for its wider comprehension, appreciation and use. Local communities will be empowered by the joint ownership of the technical-local soil knowledge base constructed during this process. The two-way improvement of communication channels will likely improve the communication of farmer's perceptions to extension agents and researchers as well as make recommendations by extension agents and NGOs better understood by the farm community. Better communication opens opportunities for established and/or emerging local organizations to use the methodological approach for consensus building that precedes any collective actions for improved natural resource management through integrated soil management.

\section{Conclusions}

The considerable importance of local knowledge in guiding future research and development efforts towards a sustainable management of natural resources is highlighted in this study. The case studies presented showed that there is a consistent rational basis to the use of local indicators of soil quality. The use of key informants was an effective method to elicit local information about soils and their management. In addition, participatory approaches involving group dynamics and consensus building are likely to be key to improve soil management beyond the farm-plot scale to the landscape scale through the required collective action process. 
Native plants as local indicators of soil quality were important local indicators of soil quality in all three case studies associated with modifiable soil properties. The use of indicator plants, belonging to the local knowledge base, when related to management actions could ease adoption of improved technologies. This approach would allow the use of plants as indicators of soil quality to which local farmers can relate more closely than to common agronomic measures such as phosphorus availability, organic matter content or $\mathrm{pH}$ value. Additional research could also include further integration of scientific spatial analysis (i.e. GIS, topographic modeling) with the spatial perception of natural resources by farmers aiming at improved implementation of site-specific management.

\section{Acknowledgements}

Special thanks are given to the farm communities from Mapire (Venezuela), Cabuyal watershed (Colombia) and Tascalapa watershed (Honduras) for sharing their ample knowledge about soils and their management. The authors are also thankful to R.J. Thomas, S.E. Cook and T. Oberthur for their valuable comments in the earlier versions of this manuscript. Financial support was provided by UNESCO-MAB for the studies in Venezuela and by the Managing Acid Soils consortium of the CGIAR systemwide program on Soils, Water and Nutrient Management for the studies in Colombia and Honduras.

\section{References}

Altieri, M.A., 1990. Why study traditional agriculture? In: Carrol, C.R., Vandermeer, J.H., Rosset, P. (Eds.), Agroecology. McGraw-Hill, New York, NY, pp. 551-564.

Anderson, J.M., Ingram, J.S.I., 1989. Tropical Soil Biology and Fertility: A Handbook of Methods, 1st ed. CAB International, London.

Barrios, E., 1997. Managing nutrients in the Orinoco floodplain. Nature and Resources 32 (4), 15-19.

Barrios, E., Escobar, E., 1998. Native plants as indicators of soil quality in the Cabuyal River watershed. CIAT Working Document.

Barrios, E., Herrera, R., Valles, J.L., 1994. Tropical floodplain agroforestry systems in mid-Orinoco River basin Venezuela. Agroforestry Systems 28, 143-157.

Brown, S., Anderson, J.M., Woomer, P.L., Swift, M.J., Barrios, E., 1994. Soil biological processes in tropical ecosystems. In: Woomer, P.L., Swift, M.J. (Eds.), Biological Management of Soil Fertility. Wiley, UK, pp. 15-46. Chap. 2.

Cerón, P., 2000. Uso, manejo y clasificación local de suelos entre agricultores de la microcuenca Potrerillo, Cauca. MSc Thesis. Universidad Nacional de Colombia, Palmira.

Chambers, R., 1983. Rural Development: Putting the Last First. Longmans, London, UK.

CIRAN, 1993. Indigenous knowledge resource centres. Indigenous Knowledge \& Development Monitor 1 (2), 48.

Cook, S.E., Adams, M.L., Corner, R.J., 1998. On-farm experiments to determine site-specific response to variable inputs. In: Robert, P.C. (Ed.), Fourth International Conference on Precision Agriculture. ASA/ CSSA/SSSA, ASPRS, PPI, St. Paul, Minnesota.

Defoer, T., Budelman, A. (Eds.), 2000. Managing Soil Fertility in the Tropics. A Resource Guide for Participatory Learning and Action Research. KIT Publishers, The Netherlands.

Hecht, S.B., 1990. Indigenous soil management in the Latin American tropics: neglected knowledge of native peoples. In: Altieri, M.A., Hecht, S.B. (Eds.), Agroecology and Small Farm Development. CRC Press, Boca Raton, FL, USA, pp. 151-157. 
Jenny, H., 1941. Factors of Soil Formation. McGraw-Hill, New York.

Jenny, H., 1980. The Soil Resource: Origin and Behavior. Springer, New York.

Paniagua, A., Kammerbauer, J., Avedillo, M., Andrews, A.M., 1999. Relationship of soil characteristics to vegetation successions on a sequence of degraded and rehabilitated soils in Honduras. Agriculture, Ecosystems \& Environment 72, 215-225.

Pawluk, R.R., Sandor, J.A., Tabor, J.A., 1992. The role of indigenous soil knowledge in agricultural development. Journal of Soil and Water Conservation 47 (4), 298-302.

Salamanca, L.X., 2000. Estudio exploratorio sobre plantas indicadoras de calidad del suelo en la microcuenca del río Cabuyal, Cauca. Trabajo Especial. Universidad Nacional de Colombia, Palmira.

Sanchez, P.A., 1976. Properties and Management of Soils in the Tropics. Wiley, New York, NY, USA.

Sandor, J.A., Furbee, L., 1996. Indigenous knowledge and classification of soils in the Andes of southern Peru. Soil Science Society of America Journal 60, 1502-1512.

Talawar, S., 1996. Local soil classification and management practices: bibliographic review. Research paper \#2. Laboratory of Agricultural and Natural Resource Anthropology. Department of Anthropology, University of Georgia, Athens, USA.

Thomas, R.J., Delve, R., Dreschel, P., Penning de Vries, F., Pala, M., 2000. Sustainable land management: contributions from the systemwide soil, water and nutrient management program. Proceedings of Meeting on Integrated Natural Resource Management, Penang, Malaysia. Future Harvest/CGIAR, in press.

Trejo, M.T., Barrios, E., Turcios, W., Barreto, H., 1999. Método Participativo para identificar y clasificar Indicadores Locales de Calidad del Suelo a nivel de Microcuenca. Instrumentos Metodológicos para la Toma de Decisiones en el Manejo de los Recursos Naturales. CIAT, CIID, BID, COSUDE.

Turcios, W., Trejo, M.T., Barreto, H., 1998. Local indicators of soil quality. Results from the Tascalapa River watershed, Yorito and Sulaco, Honduras. CIAT, Honduras. CIAT working document.

Walker, D.H., Sinclair, F.L., Thapa, B., 1995. Incorporation of indigenous knowledge and perspectives in agroforestry development: Part I. Review of methods and their application. Agroforestry Systems 30, $235-248$.

Warren, D.M., 1991. Using indigenous knowledge in agricultural development. Discussion paper no. 127. The World Bank, Washington DC, USA.

Winklerprins, A.M.G.A., 1999. Local soil knowledge: a tool for sustainable management. Society \& Natural Resources 12, 151-161. 